\title{
Effect of prolonged antibiotic treatment on cognition in patients with Lyme borreliosis
}

Anneleen Berende, MD, MSc, Hadewych J.M. ter Hofstede, MD, PhD, Fidel J. Vos, MD, PhD, Michiel L. Vogelaar, MSc, Henriët van Middendorp, PhD, Andrea W.M. Evers, PhD, Roy P.C. Kessels, PhD, and Bart Jan Kullberg, MD, PhD

Neurology ${ }^{\circledR}$ 2019;92:e1447-e1455. doi:10.1212/WNL.0000000000007186

\section{Abstract}

\section{Objective}

To investigate whether longer-term antibiotic treatment improves cognitive performance in patients with persistent symptoms attributed to Lyme borreliosis.

\section{Methods}

Data were collected during the Persistent Lyme Empiric Antibiotic Study Europe (PLEASE) trial, a randomized, placebo-controlled study. Study participants passed performance-validity testing (measure for detecting suboptimal effort) and had persistent symptoms attributed to Lyme borreliosis. All patients received a 2-week open-label regimen of intravenous ceftriaxone before the 12-week blinded oral regimen (doxycycline, clarithromycin/hydroxychloroquine, or placebo). Cognitive performance was assessed at baseline and after 14, 26, and 40 weeks with neuropsychological tests covering the cognitive domains of episodic memory, attention/ working memory, verbal fluency, speed of information processing, and executive function.

\section{Results}

Baseline characteristics of patients enrolled $(n=239)$ were comparable in all treatment groups. After 14 weeks, performance on none of the cognitive domains differed significantly between the treatment arms $(p=0.49-0.82)$. At follow-up, no additional treatment effect $(p=$ $0.35-0.98)$ or difference between groups $(p=0.37-0.93)$ was found at any time point. Patients performed significantly better in several cognitive domains at weeks 14, 26, and 40 compared to baseline, but this was not specific to a treatment group.

\section{Conclusions}

A 2-week treatment with ceftriaxone followed by a 12-week regimen of doxycycline or clarithromycin/hydroxychloroquine did not lead to better cognitive performance compared to a 2-week regimen of ceftriaxone in patients with Lyme disease-attributed persistent symptoms.

\section{ClinicalTrials.gov identifier}

NCT01207739.

\section{Classification of evidence}

This study provides Class II evidence that longer-term antibiotics in patients with borreliosisattributed persistent symptoms does not increase cognitive performance compared to shorterterm antibiotics.

\author{
Correspondence \\ Dr. Berende \\ Anneleen.Berende@ \\ radboudumc.nl
}

\section{MORE ONLINE}

$\rightarrow$ Class of Evidence

Criteria for rating

therapeutic and diagnostic studies

NPub.org/coe

\section{ค Podcast \\ Dr. Jeffrey Ratliff talks with \\ Dr. Anneleen Berende about her paper on the effect of prolonged antibiotic treatment on cognition in patients with Lyme borreliosis. \\ NPub.org/s40f5s}

\section{- CME Course}

NPub.org/cmelist 


\section{Glossary}

EOT $=$ end of treatment; Ig = immunoglobulin; PLEASE = Persistent Lyme Empiric Antibiotic Study Europe.

Many patients who experience persistent symptoms that are attributed to Lyme borreliosis complain of cognitive problems such as memory loss, word-finding difficulties, and concentration problems. ${ }^{1,2}$ However, previous studies have failed to show significant correlations between subjective memory complaints and objective test performances in patients with Lyme borreliosis and other patients. ${ }^{3-6}$ This makes assessing neurocognitive function with objective neuropsychological tests important.

Several small studies have investigated the neurocognitive performance of patients with Lyme disease compared to healthy participants. Most found a worse performance in the patient group. ${ }^{6-13}$ Deficits observed in patients with persistent symptoms attributed to Lyme disease are best typified as a combination of reduced processing speed and memory problems. ${ }^{9}$

To date, it is unknown whether the cognitive problems reported by patients with persistent Lyme disease-attributed symptoms are due to an insufficiently treated low-grade Borrelia burgdorferi infection, remnants of past infection, or incorrect attribution to Lyme borreliosis. Although most guidelines recommend antimicrobial therapy for a maximum of 2 to 4 weeks, ${ }^{14,15}$ others recommend longer-term antibiotic treatment. ${ }^{16}$

Previous studies have not been conclusive in proving the effects of longer-term antibiotic therapy on cognition. ${ }^{5,17-20}$ Furthermore, the trials performed were small $(n=129$ and $n=37)$. The present study, the largest to date, was performed to evaluate the effect of prolonged antimicrobial treatment compared to shorter-term treatment on neurocognitive function in patients with symptoms attributed to Lyme borreliosis.

\section{Methods}

\section{Study design and participants}

The data for this neurocognitive study were collected as secondary outcomes of the Persistent Lyme Empiric Antibiotic Study Europe (PLEASE), a multicenter, placebo-controlled, double-blind randomized clinical trial that was performed in the Netherlands at 2 locations (Sint Maartenskliniek and Radboud University Medical Center). From October 2010 through June 2013, patients were enrolled in this trial. The study design and protocol, inclusion and exclusion criteria, ${ }^{21}$ and main outcomes were previously published. ${ }^{22}$ Patients with ongoing symptoms such as musculoskeletal pain, neuralgia, sensory disturbances, or cognitive complaints were included if they also had B burgdorferi immunoglobulin (Ig) $\mathrm{G}$ or IgM antibodies or if the complaints were temporally linked to an erythema migrans or otherwise proven symptomatic Lyme borreliosis.

\section{Standard protocol approvals, registrations, and patient consents}

The local ethics committee has approved the PLEASE protocol (CMO region Arnhem-Nijmegen, 2009/187, NL27344.091.09). All participants provided written informed consent. The trial was registered with ClinicalTrials.gov (NCT01207739).

\section{Randomization and masking}

Computerized randomization distributed patients into 3 groups in a 1:1:1 ratio. The randomization was balanced by minimization for duration of symptoms ( $<1$ or $\geq 1$ year), age $(<40$ or $\geq 40$ years), sex, and baseline RAND-36 Health Status Inventory Global Health Composite score. ${ }^{23}$ An independent web manager entered the randomization list, consisting of consecutive medication numbers, into a secured web-based database. None of the participants or personnel involved in the trial (apart from the web manager and study pharmacist) were aware of the assignments to study groups.

\section{Classification of evidence}

The primary research question is whether longer-term antibiotic treatment with 2 weeks of ceftriaxone followed by 12 weeks of doxycycline or clarithromycin/hydroxychloroquine improves cognitive performance in patients with persistent symptoms attributed to Lyme borreliosis compared to shorterterm antibiotic treatment with 2 weeks of ceftriaxone. This trial provides Class II evidence that longer-term treatment does not lead to additional improvement.

\section{Intervention}

All patients were treated with open-label intravenous ceftriaxone daily for 2 weeks. After completion, patients started on a blinded and randomized 12-week oral regimen of doxycycline, clarithromycin-hydroxychloroquine, or placebo. The study drugs and placebo had an identical appearance. More details on the intervention have been provided in the study protocol of the PLEASE trial. ${ }^{21}$

\section{Procedures}

Cognitive performance was assessed at baseline, after end of treatment (EOT) at 14 weeks, at 26 weeks, and at 40 weeks with an extensive neuropsychological test battery covering the 5 major cognitive domains: episodic memory, attention/ working memory, fluency, speed of information processing, and executive function. We measured episodic memory with the Rey Auditory Verbal Learning Test, attention/working memory with the Digit Span Test, language with the Category Fluency Test, and speed of information processing with the Trail Making Test Part A, the average speed of cards I and II from the Stroop Color-Word Test, and the Symbol-Digit Substitution Test. We assessed executive function with the 


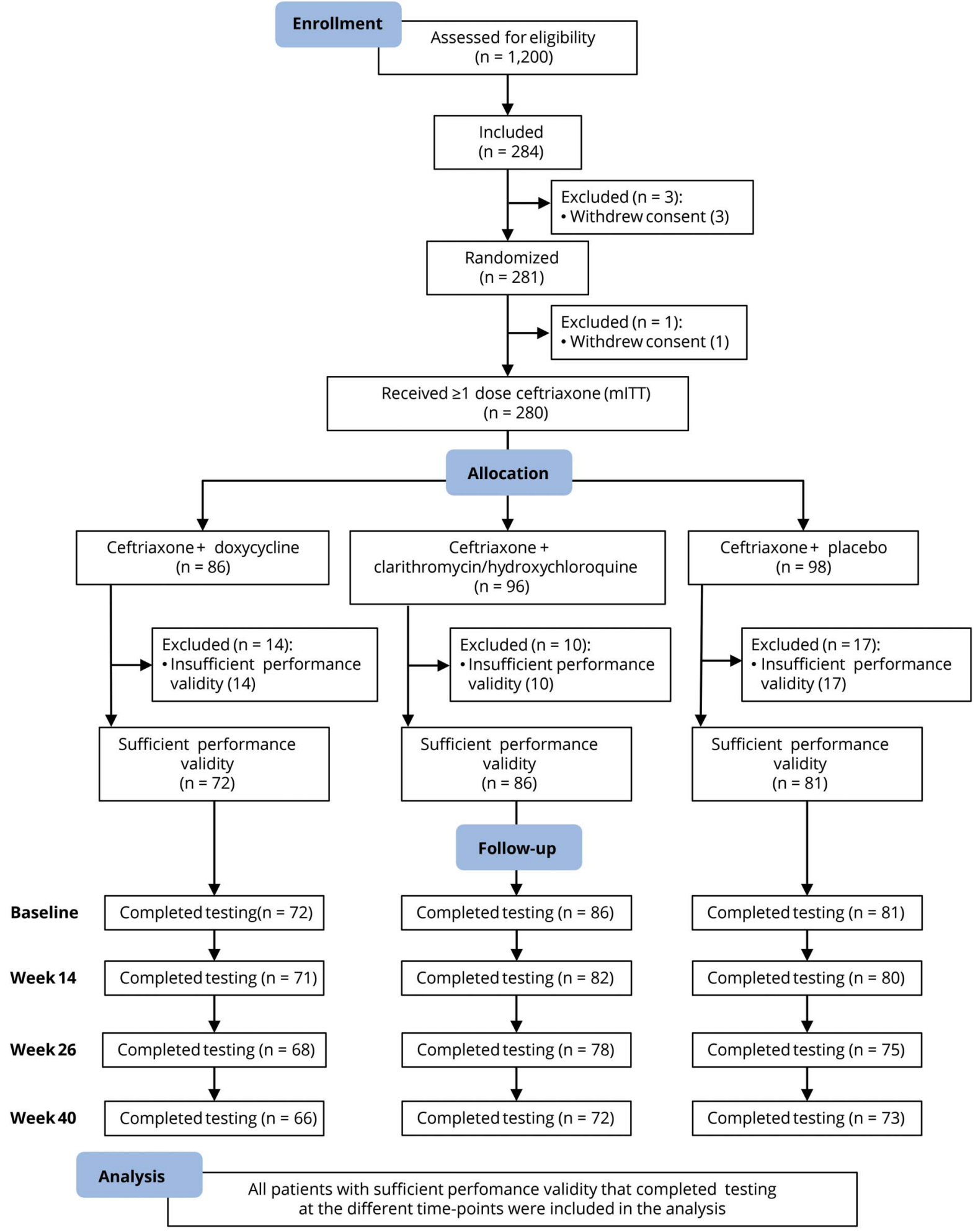

Trail Making Test Interference Score (Part B/Part A) and the Stroop Interference Score (card III/average of cards I and II). The raw test scores were standardized into $z$ scores by use of the pooled mean of baseline scores of the entire study sample. The compound score for each cognitive domain was obtained by calculating the mean of the $z$ scores for tests making up that domain. Higher scores represent better performance. Further details on the neuropsychological assessment 
Table 1 Baseline characteristics ${ }^{a}$

\begin{tabular}{|c|c|c|c|}
\hline Characteristic & $\begin{array}{l}\text { Ceftriaxone + doxycycline } \\
(n=72)\end{array}$ & $\begin{array}{l}\text { Ceftriaxone + clarithromycin/ } \\
\text { hydroxychloroquine }(n=86)\end{array}$ & $\begin{array}{l}\text { Ceftriaxone }+ \\
\text { placebo }(n=81)\end{array}$ \\
\hline Female sex, n (\%) & $33(46)$ & $37(43)$ & $39(48)$ \\
\hline Age $($ mean $\pm S D)$, y & $48.3(12.6)$ & $47.5(13.0)$ & $50.3(9.9)$ \\
\hline White, n (\%) & $70(97)$ & $86(100)$ & $81(100)$ \\
\hline \multicolumn{4}{|l|}{ Current symptoms, $\mathrm{n}(\%)^{\mathrm{b}}$} \\
\hline Arthralgia & $67(93)$ & $77(90)$ & $72(89)$ \\
\hline Musculoskeletal pain & $61(85)$ & $69(80)$ & $63(78)$ \\
\hline Sensory disturbances & $50(69)$ & $67(78)$ & $65(81)$ \\
\hline Neuralgia & $6(8)$ & $12(14)$ & $14(17)$ \\
\hline Neurocognitive symptoms & $63(88)$ & $72(84)$ & $72(89)$ \\
\hline Fatigue & $70(97)$ & $82(95)$ & $76(94)$ \\
\hline Duration of symptoms, median (IQR), y & $2.7(1.3-7.6)$ & $2.8(1.4-5.5)$ & $2.3(0.9-6.2)$ \\
\hline \multicolumn{4}{|l|}{ History of Lyme disease, $\mathrm{n}(\%)^{\mathrm{b}}$} \\
\hline Tick bite & $39(55)$ & $43(51)$ & $48(60)$ \\
\hline Erythema migrans $^{c}$ & $21(29)$ & $22(26)$ & $24(30)$ \\
\hline Acrodermatitis chronica atrophicans ${ }^{d}$ & $0(0)$ & $1(1)$ & $1(1)$ \\
\hline Borrelia meningoradiculitis $^{e}$ & $1(1)$ & $8(9)$ & $4(5)$ \\
\hline \multicolumn{4}{|l|}{ Previous use of antimicrobial treatment } \\
\hline Yes, n (\%) & $64(89)$ & $77(90)$ & $73(90)$ \\
\hline Duration, median (IQR), d & $40(28-56)$ & $30(21-44)$ & $31(28-55)$ \\
\hline \multicolumn{4}{|l|}{ Education level, $n(\%)^{f}$} \\
\hline Low ( $\leq 8$ y of education) & $1(1.4)$ & $0(0)$ & $0(0)$ \\
\hline Average (9-11 y of education) & $39(54.9)$ & $40(46.5)$ & $34(42.5)$ \\
\hline High ( $\geq 12 \mathrm{y}$ of education) & $31(43.7)$ & $46(53.5)$ & $46(57.5)$ \\
\hline \multicolumn{4}{|l|}{ Employment, ${ }^{\mathrm{b}} \mathrm{n}(\%)$} \\
\hline Working & $37(51.4)$ & $58(67.4)$ & $59(73.8)^{\mathrm{h}}$ \\
\hline Student & $3(4.2)$ & $5(5.8)$ & $2(2.5)$ \\
\hline Disabled or on sick leave & $29(40.3)$ & $28(32.6)$ & $24(29.6)$ \\
\hline Retired & $9(12.5)$ & $6(7.0)$ & $7(9.2)$ \\
\hline \multicolumn{4}{|c|}{ Cognitive domain compound score, ${ }^{\mathrm{g}}$ mean $(95 \% \mathrm{Cl})$} \\
\hline Episodic memory & $-0.08(-0.29$ to 0.12$)$ & $0.06(-0.12$ to 0.24$)$ & $0.19(0.02$ to 0.37$)$ \\
\hline Attention/working memory & $-0.11(-0.35$ to 0.13$)$ & $0.26(0.06$ to 0.46$)$ & $0.06(-0.17$ to 0.29$)$ \\
\hline Verbal fluency & $-0.09(-0.31$ to 0.13$)$ & $-0.01(-0.22$ to 0.20$)$ & $0.18(-0.06$ to 0.41$)$ \\
\hline Speed of information processing & $0.00(-0.20$ to 0.19$)$ & $0.12(-0.04$ to 0.28$)$ & $0.10(-0.08$ to 0.27$)$ \\
\hline Executive function & $-0.02(-0.21$ to 0.17$)$ & $0.04(-0.14$ to 0.23$)$ & $0.11(-0.06$ to 0.27$)$ \\
\hline \multicolumn{4}{|c|}{$\begin{array}{l}\text { Abbreviations: } \mathrm{Cl}=\text { confidence interval; IQR }=\text { interquartile range. } \\
\text { a Between-group differences were analyzed with } \chi^{2} \text { tests for proportions, analysis of variance for continuous variables, and Fisher exact test for small } \\
\text { numbers. Kruskal-Wallis tests were used for ordinal and not normally distributed data. } \\
\text { b Categories are not mutually exclusive. } \\
\text { ' Temporally related: physician-confirmed diagnosis, maximum } 4 \text { months before onset of symptoms. } \\
\text { d Temporally related: biopsy or physician-confirmed diagnosis, maximum } 4 \text { months before onset of symptoms. } \\
\text { e Temporally related: diagnosis by intrathecal Borrelia immunoglobulin } \mathrm{G} \text { synthesis, maximum } 4 \text { months before onset of symptoms. } \\
\text { f Education was assessed in accordance with the Dutch education system. }{ }^{30} \\
\mathrm{~g}^{\mathrm{T}} \text { The } z \text { scores were computed from the pooled mean of baseline scores of the entire study sample. For each cognitive domain, a compound score was derived } \\
\text { by computing the mean of the } z \text { scores for tests making up that domain. Higher scores represent better performance. } \\
{ }^{h} p<0.05 \text {. }\end{array}$} \\
\hline
\end{tabular}


have been published previously in a report on our protocol. ${ }^{21}$ Furthermore, we administered the Amsterdam Short Term Memory Test at baseline to identify participants who displayed suboptimal effort affecting performance validity. This test only appears to be a difficult task; even patients with brain damage can perform well. ${ }^{24}$ Poor performance on this task indicates suboptimal mental effort. The cutoff score for this performance validity test is 85 points (maximum score 90 ), with a sensitivity of $86 \%$ and a specificity of $87 \%$. Because we aimed to obtain an optimal specificity (i.e., $>90 \%$ ), we included only patients scoring $\geq 83$ points (with a specificity of $93 \%$ ) in the analyses to exclude participants who displayed suboptimal effort. ${ }^{24,25}$

\section{Statistical analysis}

In this study, we report secondary outcomes of the main trial, the PLEASE study. The analyses include only patients who were randomly assigned to a study group, received at least 1 dose of ceftriaxone (modified intention-to-treat population), and displayed sufficient performance validity at baseline (Amsterdam Short Term Memory Test score $\geq 83$ ). For descriptive purposes, we also classified individuals at baseline as having a clinically impaired cognitive performance using Multivariate Normative Comparisons ${ }^{26}$ based on a large Dutch normative data set from the Advanced Neuropsychological Diagnostic Infrastructure. ${ }^{27}$

We compared the 3 study groups at week 14 (EOT) with analysis of covariance, including baseline domain score as a covariate. Missing data at week 14 were imputed if they occurred in $<5 \%$ of the cases ${ }^{28}$ with the mean of the treatment group at that assessment moment. We performed linear mixed models to estimate the duration of the potential intervention effect, including all 3 posttreatment assessments (14, 26 , and 40 weeks). All models contained the baseline value of the dependent variable, time, study group treatment, and timeby-treatment interaction.

The $\alpha$ level was set at 0.05 ( 2 tailed), and 95\% confidence intervals are reported when appropriate. For pairwise comparisons of the 5 domains among the 3 study groups at different endpoints, Bonferroni correction was used (by adjusting $\alpha$ to 0.01 ) to reduce the probability of family-wise (type I) error. Sensitivity analyses included all analyses without imputation. SPSS software version 22 was used to perform the statistical analyses.

\section{Data availability}

Anonymized data, related documents such as study protocol, and statistical analysis will be shared by request from any qualified investigator for 5 years after the date of publication.

\section{Results}

Of the 281 patients randomized, $85 \%(\mathrm{n}=239)$ displayed sufficient performance validity on the cognitive tests at baseline (figure 1). No baseline differences were found between the

Table 2 Neuropsychological performance at EOT (14 weeks) ${ }^{a}$

\begin{tabular}{|c|c|c|c|c|}
\hline Cognitive domain & $\begin{array}{l}\text { Ceftriaxone + doxycycline } \\
(n=72)\end{array}$ & $\begin{array}{l}\text { Ceftriaxone + clarithromycin/ } \\
\text { hydroxychloroquine }(n=86)\end{array}$ & $\begin{array}{l}\text { Ceftriaxone }+ \\
\text { placebo }(n=81)\end{array}$ & $p$ Value \\
\hline Episodic memory & & & & 0.70 \\
\hline Mean z score $(95 \% \mathrm{CI})$ & $0.19(0.03$ to 0.35$)$ & $0.27(0.13$ to 0.41$)$ & $0.27(0.12$ to 0.42$)$ & \\
\hline Difference with placebo $(95 \% \mathrm{CI})$ & $-0.08(-0.34$ to 0.18$)$ & $0.00(-0.25$ to 0.25$)$ & - & \\
\hline Attention/working memory & & & & 0.65 \\
\hline Mean z score $(95 \% \mathrm{CI})$ & $0.21(0.05$ to 0.37$)$ & $0.16(0.01$ to 0.30$)$ & 0.25 (0.10 to 0.40$)$ & \\
\hline Difference with placebo $(95 \% \mathrm{CI})$ & $-0.04(-0.30$ to 0.22$)$ & $-0.10(-0.35$ to 0.16$)$ & - & \\
\hline Verbal fluency & & & & 0.60 \\
\hline Mean z score $(95 \% \mathrm{CI})$ & $0.18(0.02$ to 0.35$)$ & $0.24(0.09$ to 0.39$)$ & $0.13(-0.03$ to 0.28$)$ & \\
\hline Difference with placebo $(95 \% \mathrm{CI})$ & $0.06(-0.22$ to 0.34$)$ & $0.11(-0.16$ to 0.38$)$ & - & \\
\hline Speed of information processing & & & & 0.49 \\
\hline Mean z score $(95 \% \mathrm{CI})$ & $0.25(0.15$ to 0.36$)$ & $0.30(0.21$ to 0.39$)$ & $0.34(0.24$ to 0.44$)$ & \\
\hline Difference with placebo $(95 \% \mathrm{CI})$ & $-0.09(-0.26$ to 0.09$)$ & $-0.04(-0.20$ to 0.13$)$ & - & \\
\hline Executive function & & & & 0.82 \\
\hline Mean z score $(95 \% \mathrm{CI})$ & $0.14(-0.01$ to 0.28$)$ & $0.13(0.00$ to 0.27$)$ & $0.19(0.05$ to 0.32$)$ & \\
\hline Difference with placebo $(95 \% \mathrm{CI})$ & $-0.05(-0.30$ to 0.19$)$ & $-0.05(-0.29$ to 0.18$)$ & - & \\
\hline
\end{tabular}


3 treatment groups, including baseline neuropsychological performance (table 1), apart from the percentage of patients with a job, which significantly differed between groups. At baseline, 7 of 239 patients were classified as having a clinically impaired cognitive performance compared to Dutch normative data.

The neuropsychological performance (i.e., the mean $z$ score per domain) at EOT (14 weeks), corrected for baseline performance and sex, did not significantly differ between treatment groups for any of the domains, with $p$ values ranging from 0.49 to 0.82 (table 2).

Figure 2 shows the mean performance per group for each neuropsychological domain over time. The differences between the various time points compared to baseline are depicted in table 3 . The performance on 2 domains, episodic memory and speed of information, significantly improved between baseline and EOT in all randomization groups. Similarly, at 26 and 40 weeks, several domains showed higher scores compared to baseline.

However, no additional long-term treatment effects were seen in mixed-model analyses (the difference between the treatment arms did not change over time) for any of the domains; $p$ values ranged from 0.35 to 0.98 for the time-by-treatment interaction. No significant difference was found between the 3 treatment groups at any time point during follow-up in neuropsychological performance either ( $p$ values ranging from 0.37 to 0.93 ). All sensitivity analyses yielded results similar to those of the main analyses. Several post hoc analyses were also done. Subset analyses with patients who had symptoms for $<1$ year $(n=46)$ did not show a significant difference between treatment groups. Excluding patients who did not

Figure 2 Mean z score (95\% confidence interval) per treatment group per neuropsychological domain at all study visits

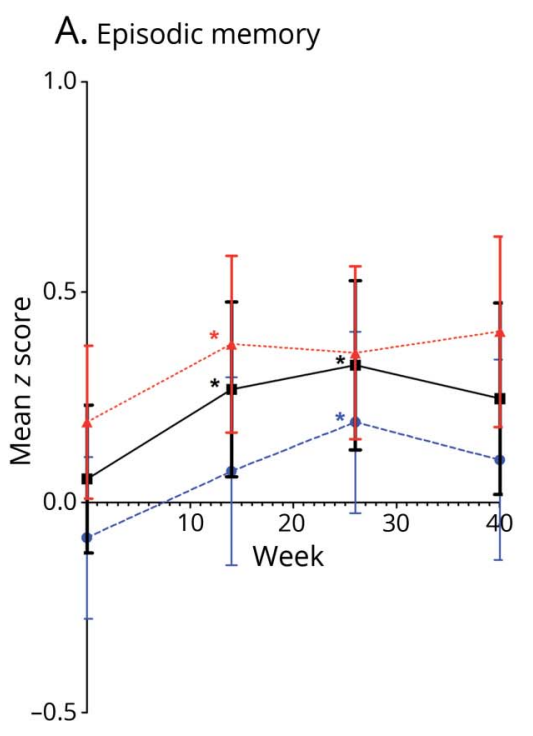

D. Speed of information processing

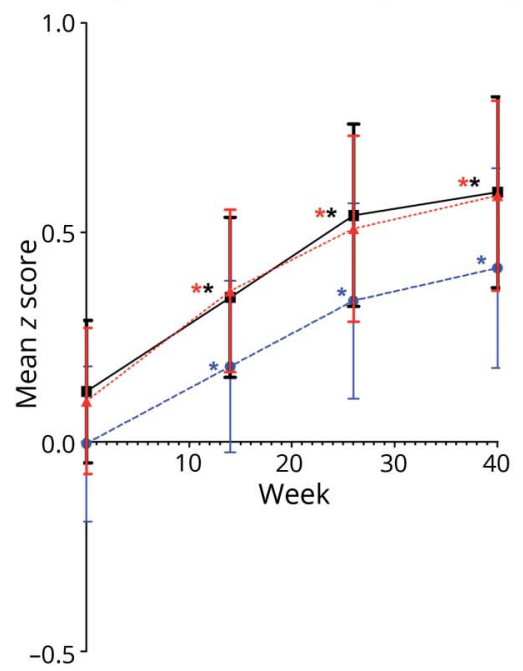

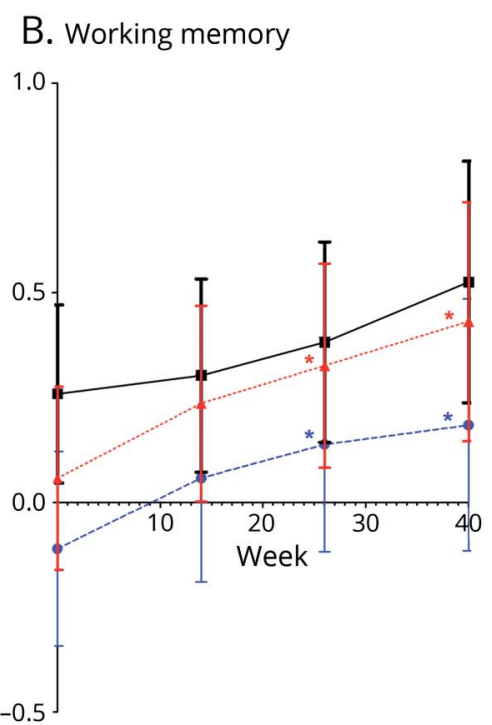
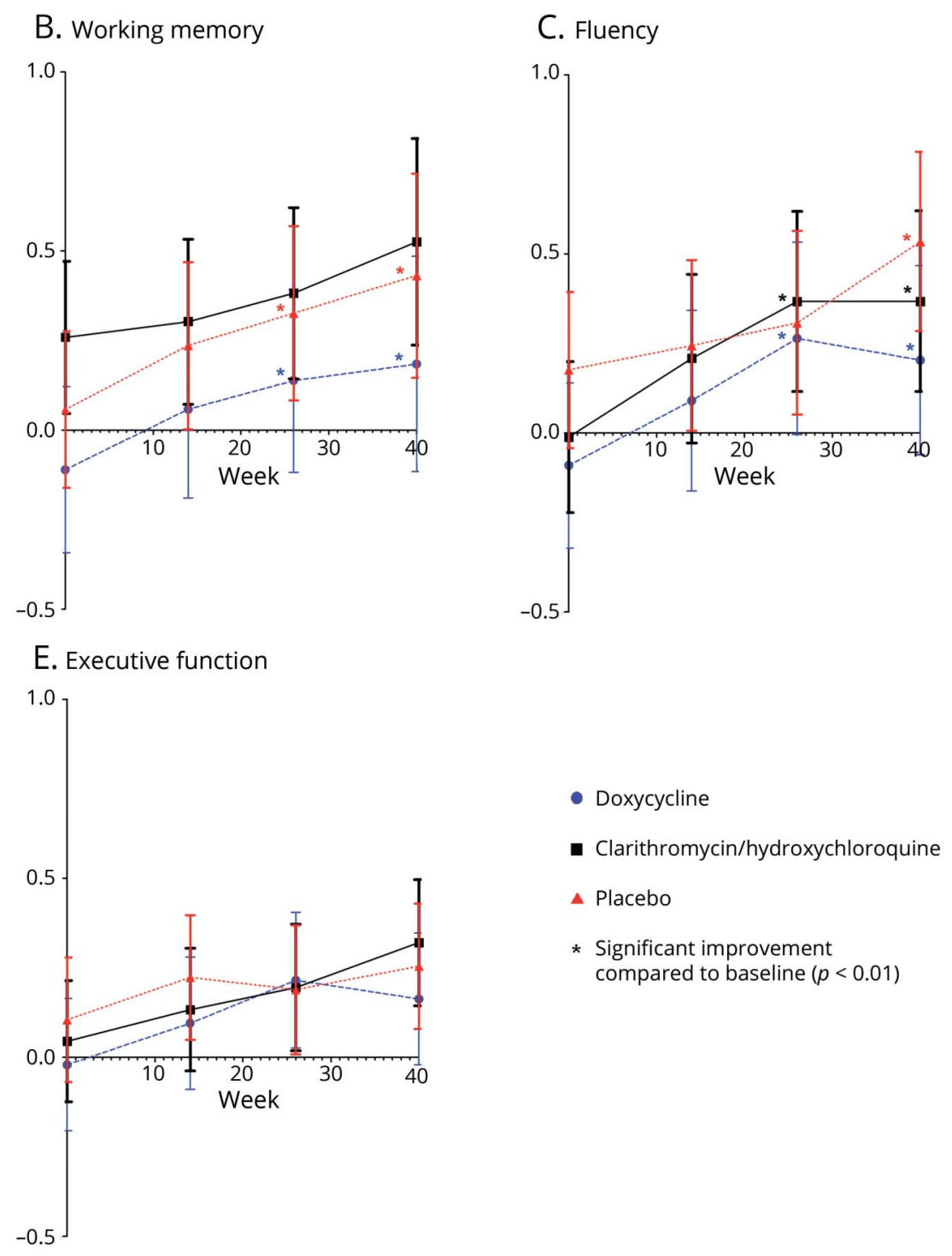

(A) Episodic memory, (B) working memory, (C) fluency, (D) speed of information processing, and (E) executive function. 
Table 3 Treatment effect at different endpoints $(14,26$, and 40 weeks compared to baseline)

\begin{tabular}{|c|c|c|c|c|c|c|}
\hline \multirow[b]{2}{*}{ Cognitive domain } & \multicolumn{2}{|l|}{ Week 14 vs baseline } & \multicolumn{2}{|l|}{ Week 26 vs baseline } & \multicolumn{2}{|l|}{ Week 40 vs baseline } \\
\hline & $\begin{array}{l}\text { Difference in mean } \\
z \text { score (SEM) }\end{array}$ & $p$ Value $^{a}$ & $\begin{array}{l}\text { Difference in mean } \\
z \text { score (SEM) }\end{array}$ & $p$ Value $^{a}$ & $\begin{array}{l}\text { Difference in mean } \\
z \text { score (SEM) }\end{array}$ & $p$ Value $^{a}$ \\
\hline \multicolumn{7}{|l|}{ Episodic memory } \\
\hline Ceftriaxone + doxycycline & $0.16(0.08)$ & 0.056 & $0.26(0.07)$ & $<0.01$ & $0.20(0.08)$ & 0.015 \\
\hline Ceftriaxone + clarithromycin & $0.22(0.08)$ & $<0.01$ & $0.27(0.07)$ & $<0.01$ & $0.18(0.07)$ & 0.017 \\
\hline Ceftriaxone + placebo & $0.19(0.07)$ & $<0.01$ & $0.14(0.08)$ & 0.090 & $0.19(0.08)$ & 0.013 \\
\hline \multicolumn{7}{|l|}{ Attention/working memory } \\
\hline Ceftriaxone + doxycycline & $0.18(0.08)$ & 0.031 & $0.26(0.07)$ & $<0.01$ & $0.32(0.10)$ & $<0.01$ \\
\hline Ceftriaxone + clarithromycin & $0.04(0.08)$ & 0.589 & $0.11(0.07)$ & 0.132 & $0.23(0.09)$ & 0.015 \\
\hline Ceftriaxone + placebo & $0.19(0.07)$ & 0.012 & $0.29(0.09)$ & $<0.01$ & $0.37(0.09)$ & $<0.01$ \\
\hline \multicolumn{7}{|l|}{ Verbal fluency } \\
\hline Ceftriaxone + doxycycline & $0.19(0.09)$ & 0.033 & $0.32(0.08)$ & $<0.01$ & $0.29(0.09)$ & $<0.01$ \\
\hline Ceftriaxone + clarithromycin & $0.20(0.09)$ & 0.025 & $0.39(0.09)$ & $<0.01$ & $0.46(0.11)$ & $<0.01$ \\
\hline Ceftriaxone + placebo & $0.09(0.08)$ & 0.245 & $0.12(0.10)$ & 0.209 & $0.35(0.09)$ & $<0.01$ \\
\hline \multicolumn{7}{|l|}{ Speed of information processing } \\
\hline Ceftriaxone + doxycycline & $0.19(0.05)$ & $<0.01$ & $0.33(0.05)$ & $<0.01$ & $0.46(0.06)$ & $<0.01$ \\
\hline Ceftriaxone + clarithromycin & $0.22(0.05)$ & $<0.01$ & $0.41(0.06)$ & $<0.01$ & $0.50(0.07)$ & $<0.01$ \\
\hline Ceftriaxone + placebo & $0.26(0.05)$ & $<0.01$ & $0.40(0.06)$ & $<0.01$ & $0.47(0.07)$ & $<0.01$ \\
\hline \multicolumn{7}{|l|}{ Executive function } \\
\hline Ceftriaxone + doxycycline & $0.11(0.07)$ & 0.1290 & $0.22(0.08)$ & 0.010 & $0.17(0.09)$ & 0.075 \\
\hline Ceftriaxone + clarithromycin & $0.10(0.08)$ & 0.1884 & $0.20(0.10)$ & 0.044 & $0.20(0.09)$ & 0.031 \\
\hline Ceftriaxone + placebo & $0.11(0.09)$ & 0.2013 & $0.10(0.08)$ & 0.185 & $0.17(0.07)$ & 0.019 \\
\hline
\end{tabular}

a Bonferroni correction was applied, i.e., a was adjusted to 0.01 .

report subjective cognitive complaints at baseline $(\mathrm{n}=32)$ did not yield different results, nor did post hoc analyses on the subgroup of patients with severe subjective symptoms as measured by the Cognitive Failures Questionnaire. ${ }^{29}$ With a cutoff value for the Cognitive Failures Questionnaire set at 44, 111 patients were considered to have severe neurocognitive symptoms. Finally, subgroup analyses including only patients who had a high burden of symptoms (i.e., those who were on sick leave or disability support, $\mathrm{n}=81$ ) also did not show a significant difference between placebo and antimicrobial treatment groups. Using analysis of covariance, with sick leave/ disability and baseline cognitive function as covariates, we found no significant difference between treatment groups.

\section{Discussion}

This study showed that prolonged antibiotic treatment for 3 months in patients with persistent Lyme borreliosis-attributed symptoms does not have an additional beneficial effect on cognitive performance compared to short-term treatment.
Previous case series have suggested a significant cognitive improvement on most domains after antibiotic treatment. ${ }^{18,19}$ Two randomized controlled treatment trials have also demonstrated significant improvement of objective test scores after treatment compared to baseline performance. ${ }^{5,17}$ However, no significant differences were found between those receiving antibiotics and those receiving placebo in 1 trial, ${ }^{5}$ and the other trial did not show sustainable effects of antibiotic treatment on cognition. ${ }^{17}$ In our trial, mixed-model analyses showed no difference over time. Cognitive improvements were found at weeks 14,26 , and 40 only when the separate domains were directly compared with baseline, and changes over time were at most in the small to moderate range. Because an improvement was seen in all treatment groups, including the placebo control group, the observed changes appear to be neither clinically relevant nor treatment specific. The global difference found over time may be the result of a placebo effect, nonspecific practice effects, spontaneous improvement over time, or a combination of these.

The present study is the largest trial performed to date. It was specifically designed prospectively to study treatment outcomes, 
including cognitive performance, using a strictly controlled design. $^{21,22}$ In addition, our study is the first to take suboptimal cognitive effort into account in the neuropsychological assessment by selecting only patients who displayed sufficient performance validity. Kaplan et al. ${ }^{5}$ have investigated the personality traits of participants and investigated symptom validity to some extent by examining the patients' ability to present a false impression using the Minnesota Multiphasic Personality Inventory-2. However, that does not compare to our way of taking suboptimal cognitive effort explicitly into account through performance validity testing.

A limitation of our study may relate to missing values. To reduce the influence of missing values, mixed-model analyses were performed. In these analyses, no significant differences between groups on any of the domains were observed.

While a ceiling effect may be considered, because only a fewpatients were overall cognitively impaired at baseline, none of the raw scores were at or near ceiling for any of the tests at various endpoints. The mean performances per test were typically in the midrange between the minimally and maximally possible scores, leaving sufficient room for improvement.

The fact that we did not include only patients with subjective cognitive complaints could be seen as another limitation. However, our patient population is representative of the real-life population of patients with Lyme borreliosis, improving the external validity. Moreover, only 32 of 280 patients did not report subjective cognitive complaints at baseline. Post hoc analyses excluding those 32 patients did not yield different results; i.e., there was no significant difference between groups at EOT.

Finally, because the study was not specifically powered for detecting neuropsychological test outcomes, the results must be seen as preliminary.

Future studies on treatment of cognitive function in individuals with Lyme borreliosis may specifically focus on the small group of patients with objectively impaired cognitive performance.

Our study suggests that cognitive performance as assessed by validated tests does not improve with longer antibiotic treatment compared to shorter-term treatment in patients with persistent symptoms attributed to Lyme borreliosis.

\section{Acknowledgment}

The authors thank Dr. Joost A. Agelink van Rentergem, University of Amsterdam, for his assistance with the Advanced Neuropsychological Diagnostics Infrastructure analyses.

\section{Study funding}

Funded by the Netherlands National Organization for Scientific Research (ID ZonMw 171002304).

\section{Disclosure}

The authors report no disclosures relevant to the manuscript. Go to Neurology.org/N for full disclosures.

\section{Publication history}

Received by Neurology August 24, 2018. Accepted in final form November 21, 2018.

Appendix Authors

\begin{tabular}{|c|c|c|c|}
\hline Name & Location & Role & Contribution \\
\hline $\begin{array}{l}\text { Anneleen } \\
\text { Berende, MD }\end{array}$ & $\begin{array}{l}\text { Radboud } \\
\text { University Medical } \\
\text { Center, Nijmegen, } \\
\text { the Netherlands }\end{array}$ & Author & $\begin{array}{l}\text { Drafting/revising the } \\
\text { manuscript for content, } \\
\text { including medical } \\
\text { writing for content; } \\
\text { study concept/design; } \\
\text { analysis/interpretation } \\
\text { of data; acquisition of } \\
\text { data; statistical } \\
\text { analysis; study } \\
\text { supervision/ } \\
\text { coordination }\end{array}$ \\
\hline
\end{tabular}

\begin{tabular}{|c|c|c|c|}
\hline $\begin{array}{l}\text { Hadewych } \\
\text { J.M. ter } \\
\text { Hofstede, } \\
\text { MD, PhD }\end{array}$ & $\begin{array}{l}\text { Radboud } \\
\text { University Medical } \\
\text { Center, Nijmegen }\end{array}$ & Author & $\begin{array}{l}\text { Revising the } \\
\text { manuscript for content, } \\
\text { including medical } \\
\text { writing for content; } \\
\text { study concept/design; } \\
\text { acquisition of data; } \\
\text { study supervision/ } \\
\text { coordination; obtaining } \\
\text { funding }\end{array}$ \\
\hline
\end{tabular}

\begin{tabular}{|c|c|c|c|}
\hline $\begin{array}{l}\text { Fidel J. Vos, } \\
\text { MD, PhD }\end{array}$ & $\begin{array}{l}\text { Sint } \\
\text { Maartenskliniek, } \\
\text { Nijmegen }\end{array}$ & Author & $\begin{array}{l}\text { Revising the } \\
\text { manuscript for content, } \\
\text { including medical } \\
\text { writing for content; } \\
\text { acquisition of data }\end{array}$ \\
\hline
\end{tabular}

\begin{tabular}{|c|c|c|c|}
\hline $\begin{array}{l}\text { Michiel L. } \\
\text { Vogelaar, }\end{array}$ & $\begin{array}{l}\text { Radboud } \\
\text { University Medical }\end{array}$ & Author & $\begin{array}{l}\text { Revising the } \\
\text { manuscript for content, }\end{array}$ \\
\hline
\end{tabular}

$\begin{array}{lll}\text { Mogelaar, } & \text { University Medical } & \text { manuscript for cont } \\ \text { MSc } & \text { including medical }\end{array}$ writing for content; analysis/interpretation of data; acquisition of data; statistical analysis

\begin{tabular}{|c|c|c|c|}
\hline $\begin{array}{l}\text { Henriët van } \\
\text { Middendorp, } \\
\text { PhD }\end{array}$ & $\begin{array}{l}\text { Leiden University, } \\
\text { Leiden, the } \\
\text { Netherlands }\end{array}$ & Author & $\begin{array}{l}\text { Revising the } \\
\text { manuscript for content, } \\
\text { including medical } \\
\text { writing for content; } \\
\text { statistical analysis }\end{array}$ \\
\hline $\begin{array}{l}\text { Andrea W.M. } \\
\text { Evers, PhD }\end{array}$ & $\begin{array}{l}\text { Leiden University, } \\
\text { Leiden }\end{array}$ & Author & $\begin{array}{l}\text { Revising the } \\
\text { manuscript for content, } \\
\text { including medical } \\
\text { writing for content; } \\
\text { study concept/design; } \\
\text { study supervision/ } \\
\text { coordination }\end{array}$ \\
\hline
\end{tabular}

\begin{tabular}{|c|c|c|c|}
\hline $\begin{array}{l}\text { Roy P.C. } \\
\text { Kessels, PhD }\end{array}$ & $\begin{array}{l}\text { Radboud } \\
\text { University, } \\
\text { Nijmegen }\end{array}$ & Author & $\begin{array}{l}\text { Drafting/revising the } \\
\text { manuscript for content, } \\
\text { including medical } \\
\text { writing for content; } \\
\text { study concept/design; } \\
\text { analysis/interpretation } \\
\text { of data; statistical } \\
\text { analysis; study } \\
\text { supervision/ } \\
\text { coordination }\end{array}$ \\
\hline
\end{tabular}

\begin{tabular}{|c|c|c|c|}
\hline $\begin{array}{l}\text { Bart Jan } \\
\text { Kullberg, MD, } \\
\text { PhD }\end{array}$ & $\begin{array}{l}\text { Radboud } \\
\text { University Medical } \\
\text { Center, Nijmegen }\end{array}$ & Author & $\begin{array}{l}\text { Revising the } \\
\text { manuscript for } \\
\text { content, including } \\
\text { medical writing for } \\
\text { content; study } \\
\text { concept/design; } \\
\text { acquisition of data; } \\
\text { study supervision/ } \\
\text { coordination; } \\
\text { obtaining funding }\end{array}$ \\
\hline
\end{tabular}




\section{References}

1. Aucott JN, Rebman AW, Crowder LA, Kortte KB. Post-treatment Lyme disease syndrome symptomatology and the impact on life functioning: is there something here? Qual Life Res 2013;22:75-84.

2. Logigian EL, Kaplan RF, Steere AC. Chronic neurologic manifestations of Lyme disease. N Engl J Med 1990;323:1438-1444.

3. Bermeo-Ovalle A. Do we know what we think we know? Reconciling subjective complaints and objective cognitive testing in older adults with epilepsy. Epilepsy Curr 2016;16:230-231.

4. Galioto R, Blum AS, Tremont G. Subjective cognitive complaints versus objective neuropsychological performance in older adults with epilepsy. Epilepsy Behav 2015; 51:48-52.

5. Kaplan RF, Trevino RP, Johnson GM, et al. Cognitive function in post-treatment Lyme disease: do additional antibiotics help? Neurology 2003;60:1916-1922.

6. Ravdin LD, Hilton E, Primeau M, Clements C, Barr WB. Memory functioning in Lyme borreliosis. J Clin Psychiatry 1996;57:282-286.

7. Eikeland R, Ljostad U, Mygland A, Herlofson K, Lohaugen GC. European neuroborreliosis: neuropsychological findings 30 months post-treatment. Eur J Neurol 2012;19:480-487.

8. Gaudino EA, Coyle PK, Krupp LB. Post-Lyme syndrome and chronic fatigue syndrome: neuropsychiatric similarities and differences. Arch Neurol 1997;54: 1372-1376.

9. Keilp JG, Corbera K, Slavov I, Taylor MJ, Sackeim HA, Fallon BA. WAIS-III and WMSIII performance in chronic Lyme disease. J Int Neuropsychol Soc 2006;12:119-129.

10. Krupp LB, Masur D, Schwartz J, et al. Cognitive functioning in late Lyme borreliosis. Arch Neurol 1991;48:1125-1129.

11. Pollina DA, Sliwinski M, Squires NK, Krupp LB. Cognitive processing speed in Lyme disease. Neuropsychiatry Neuropsychol Behav Neurol 1999;12:72-78.

12. Shadick NA, Phillips CB, Logigian EL, et al. The long-term clinical outcomes of Lyme disease: a population-based retrospective cohort study. Ann Intern Med 1994;121: $560-567$.

13. Westervelt HJ, McCaffrey RJ. Neuropsychological functioning in chronic Lyme disease. Neuropsychol Rev 2002;12:153-177.

14. Mygland A, Ljøstad U, Fingerle V, Rupprecht T, Schmutzhard E, Steiner I. EFNS guidelines on the diagnosis and management of European Lyme neuroborreliosis. Eur J Neurol 2010;17, 8-4.

15. Wormser GP, Dattwyler RJ, Shapiro ED, et al. The clinical assessment, treatment, and prevention of Lyme disease, human granulocytic anaplasmosis, and babesiosis: clinical practice guidelines by the Infectious Diseases Society of America. Clin Infect Dis 2006;43:1089-1134

16. Cameron DJ, Johnson LB, Maloney EL. Evidence assessments and guideline recommendations in Lyme disease: the clinical management of known tick bites, erythema migrans rashes and persistent disease. Expert Rev Anti Infect Ther 2014;12:1103-1135.

17. Fallon BA, Keilp JG, Corbera KM, et al. A randomized, placebo-controlled trial of repeated IV antibiotic therapy for Lyme encephalopathy. Neurology 2008;70:992-1003.

18. Halperin JJ, Pass HL, Anand AK, Luft BJ, Volkman DJ, Dattwyler RJ. Nervous system abnormalities in Lyme disease. Ann NY Acad Sci 1988;539:24-34.

19. Logigian EL, Kaplan RF, Steere AC. Successful treatment of Lyme encephalopathy with intravenous ceftriaxone. J Infect Dis 1999;180:377-383.

20. Klempner MS, Hu LT, Evans J, et al. Two controlled trials of antibiotic treatment in patients with persistent symptoms and a history of Lyme disease. N Engl J Med 2001; 345:85-92.

21. Berende A, ter Hofstede HJ, Donders AR, et al. Persistent Lyme Empiric Antibiotic Study Europe (PLEASE): design of a randomized controlled trial of prolonged antibiotic treatment in patients with persistent symptoms attributed to Lyme borreliosis. BMC Infect Dis 2014;14:543.

22. Berende A, ter Hofstede HJ, Vos FJ, et al. Randomized trial of longer-term therapy for symptoms attributed to Lyme disease. N Engl J Med 2016;374:1209-1220.

23. Hays RD. RAND-36 Health Status Inventory. San Antonio: Psychological Corp; 1998.

24. Schagen S, Schmand B, de Sterke S, Lindeboom J. Amsterdam Short-Term Memory Test: a new procedure for the detection of feigned memory deficits. J Clin Exp Neuropsychol 1997;19:43-51.

25. Schmand B, Lindeboom J. Amsterdam Short Term Memory Test: Manual. Oxford, UK: Hogrefe; 2005

26. Agelink van Rentergem JA, Murre JM, Huizenga HM. Multivariate normative comparisons using an aggregated database. PLoS One 2017;12:e0173218.

27. de Vent NR, Agelink van Rentergem JA, Schmand BA, Murre JM, Consortium A, Huizenga HM. Advanced Neuropsychological Diagnostics Infrastructure (ANDI): a normative database created from control datasets. Front Psychol 2016;7:1601.

28. Graham JW. Missing data analysis: making it work in the real world. Annu Rev Psychol 2009;60:549-576.

29. Broadbent DE, Cooper PF, FitzGerald P, Parkes KR. The Cognitive Failures Questionnaire (CFQ) and its correlates. Br J Clin Psychol 1982;21(pt 1):1-16.

30. Hochstenbach J, Mulder T, van Limbeek J, Donders R, Schoonderwaldt H. Cognitive decline following stroke: a comprehensive study of cognitive decline following stroke. J Clin Exp Neuropsychol 1998;20:503-517. 


\section{Neurology}

\section{Effect of prolonged antibiotic treatment on cognition in patients with Lyme borreliosis}

Anneleen Berende, Hadewych J.M. ter Hofstede, Fidel J. Vos, et al.

Neurology 2019;92;e1447-e1455 Published Online before print February 22, 2019

DOI 10.1212/WNL.0000000000007186

This information is current as of February 22, 2019

$\begin{array}{ll}\begin{array}{l}\text { Updated Information \& } \\ \text { Services }\end{array} & \begin{array}{l}\text { including high resolution figures, can be found at: } \\ \text { http://n.neurology.org/content/92/13/e1447.full }\end{array} \\ \text { References } & \text { This article cites } 28 \text { articles, } 2 \text { of which you can access for free at: } \\ & \text { http://n.neurology.org/content/92/13/e1447.full\#ref-list-1 } \\ & \text { This article, along with others on similar topics, appears in the } \\ \text { following collection(s): } & \text { Bacterial infections } \\ \text { hubspecialty Collections } & \text { Class II } \\ & \text { http://n.neurology.org/cgi/collection/bacterial_infections } \\ & \text { Clinical trials Randomized controlled (CONSORT agreement) } \\ & \text { http://n.neurology.org/cgi/collection/clinical_trials_randomized_contro } \\ & \text { lled_consort_agreement } \\ & \text { Neuropsychological assessment } \\ & \text { http://n.neurology.org/cgi/collection/neuropsychological_assessment } \\ & \text { Information about reproducing this article in parts (figures,tables) or in } \\ & \text { its entirety can be found online at: } \\ & \text { http://www.neurology.org/about/about_the_journal\#permissions } \\ & \text { Information about ordering reprints can be found online: } \\ \text { Permissions \& Licensing } & \text { http://n.neurology.org/subscribers/advertise }\end{array}$

Neurology ${ }^{\circledR}$ is the official journal of the American Academy of Neurology. Published continuously since 1951, it is now a weekly with 48 issues per year. Copyright Copyright ( 2019 The Author(s). Published by Wolters Kluwer Health, Inc. on behalf of the American Academy of Neurology.. All rights reserved. Print ISSN: 0028-3878. Online ISSN: 1526-632X.

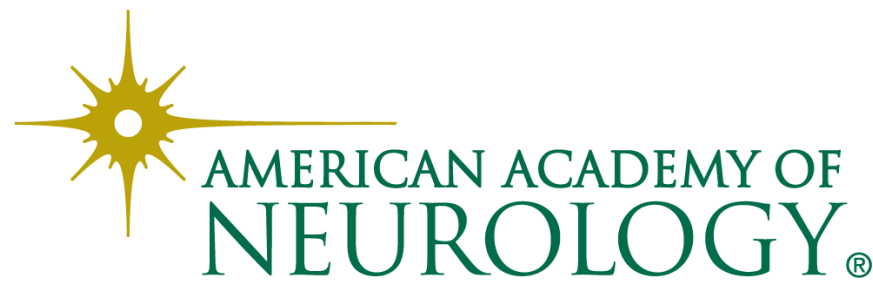

